\title{
Quarrying History and Use of the Buena Vista Freestone, South- Central Ohio: Understanding the 19th Century Industrial Development of a Geological Resource
}

\author{
DAVID B. SAJA ${ }^{1}$ and JOSEPH T. HANNIBAL, Cleveland Museum of Natural History, Cleveland, OH, USA.
}

ABSTRACT. The Buena Vista Member of the Mississippian Cuyahoga Formation is an economically valuable freestone that is homogeneous with almost no sedimentary structures. The Buena Vista was one of the earliest clastic rocks quarried in Ohio. Early quarries dating at least back to 1814 were located in the hills on the north bank of the Ohio River near the village of Buena Vista, south-central Ohio. By the 1830s, quarries had also opened up along the route of the Ohio \& Erie Canal in the Portsmouth area to the east; followed by quarries that opened along a railway line that ran north up the Scioto River valley. Waterways transported the Buena Vista to many cities and towns, including Cincinnati, Ohio, Louisville, Kentucky, and Evansville, Indiana, on the Ohio River, New Orleans on the Mississippi River, and Dayton and Columbus on the Ohio canal system. Later railways transported this stone further afield to Illinois, Wisconsin, and Alberta. Census reports, industry magazines, and other historical accounts document the use of this stone across much of the eastern US and into Canada. Historically, it has been used for a variety of items, including entire buildings, canal structures, fence posts, and laundry tubs. Some 19th-century structures built with this stone remain in cities where it was once commonly used. Literature reviews, field observations, and lab analyses are here compiled as a useful reference to both the urban and field geologist in the identification of the Buena Vista Member, a historically important building stone, in buildings and outcrops, respectively.

\section{INTRODUCTION}

Stone from the Buena Vista Member of the Cuyahoga Formation was once thought of as "one of the finest building stones of the country" (Orton 1891). In 1915, Andrews said, "For beauty, durability, firmness under pressure, ease of working and general good behavior under the chisel ... I know of no stone in the country equal to it" (Bownocker 1915). A fine-grained homogeneous sandstone, the Buena Vista Member was extremely popular with architects in the early 19th century and was shipped to many cities around the country. It continues to be quarried, but only in limited quantities for building stone.

The type locality for the Buena Vista Member was described by Orton (1874) at the town of Buena Vista located in Scioto County in south-central Ohio (Fig. 1). At Buena Vista, the rock crops out as ledges on the hillsides along the Ohio River. The Buena Vista Member occurs stratigraphically near the bottom of the Lower Mississippian Cuyahoga Formation (Fig. 2), but above the similar looking and generally coarser Upper Devonian Berea Sandstone. The Buena Vista Member crops out in a roughly north northeast-south southwest

${ }^{1}$ Address correspondence to David B. Saja, Cleveland Museum of Natural History, 1 Wade Oval Drive, Cleveland, OH 441061767. E-mail: dsaja@cmnh.org trending region (Fig. 1), limited to Adams, Scioto, Pike, and southern Ross counties in south-central Ohio (Hyde 1953). And, in 1838, Locke had already documented the Buena Vista Member as dipping 9.5 degrees to the east (Evans and Stivers 1900).

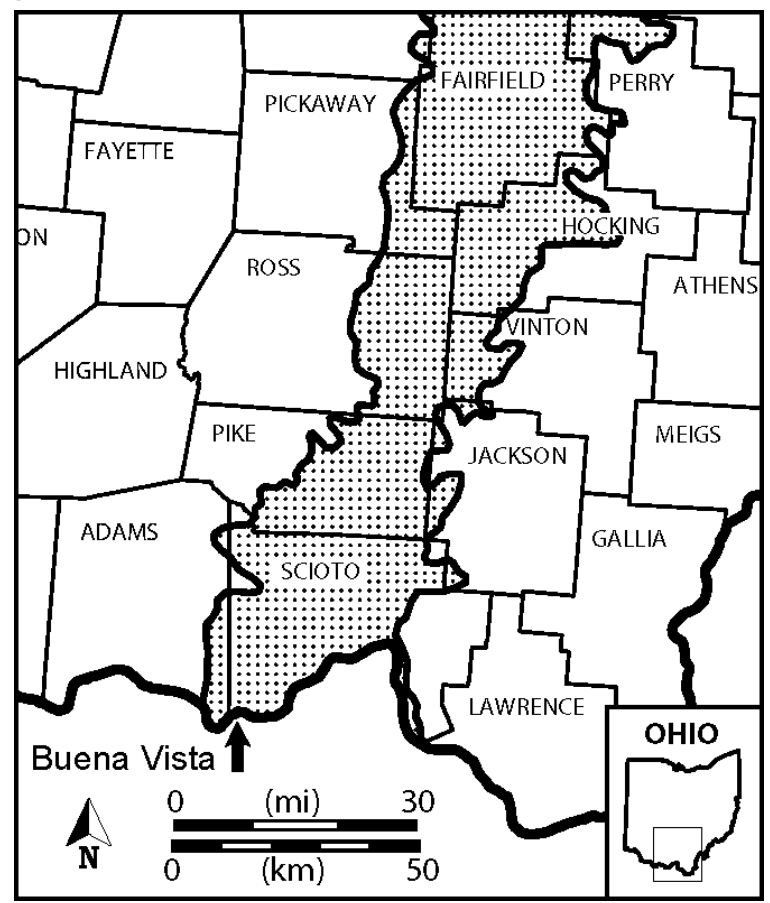

FIGURE 1. Map showing location of the town of Buena Vista at the joining southern corners of Adams and Scioto counties in southcentral Ohio, and the geographic region where Mississippian rocks crop out, including the Buena Vista Member. 
To the south across the Ohio River in Kentucky, similar beds stratigraphically corresponding to those of the Buena Vista continue along the same geographic trend as in Ohio, cropping out in Lewis, Fleming, Rowan, and Bath counties in central Kentucky (Stockdale 1939). These beds have been quarried as far south as Stanton, Powell County, Kentucky (Butts 1922). At this point the sandstone beds begin to pinch out and vary in thickness as the unit increases in shale content (Stockdale 1939). These equivalent beds in Kentucky are referred to as the Farmers Member of the Borden Formation, after stone described in the Rowen County Freestone Company quarry at the village of Farmers (Ettensohn et al. 1992).

The purpose of this paper is to review the quarrying history of the Buena Vista Member in southern Ohio; identify and document existing buildings made of this stone; and to provide petrographic characteristics of the Buena Vista Member for identification. It adds new observations about the material behavior and sources of the Buena Vista Member in addition to a condensed review of published facts. Together they provide an important resource to architects and historical preservationists working nationally, as well as field geologists working in the Ohio, Indiana, Pennsylvania, Kentucky, and West Virginia region.

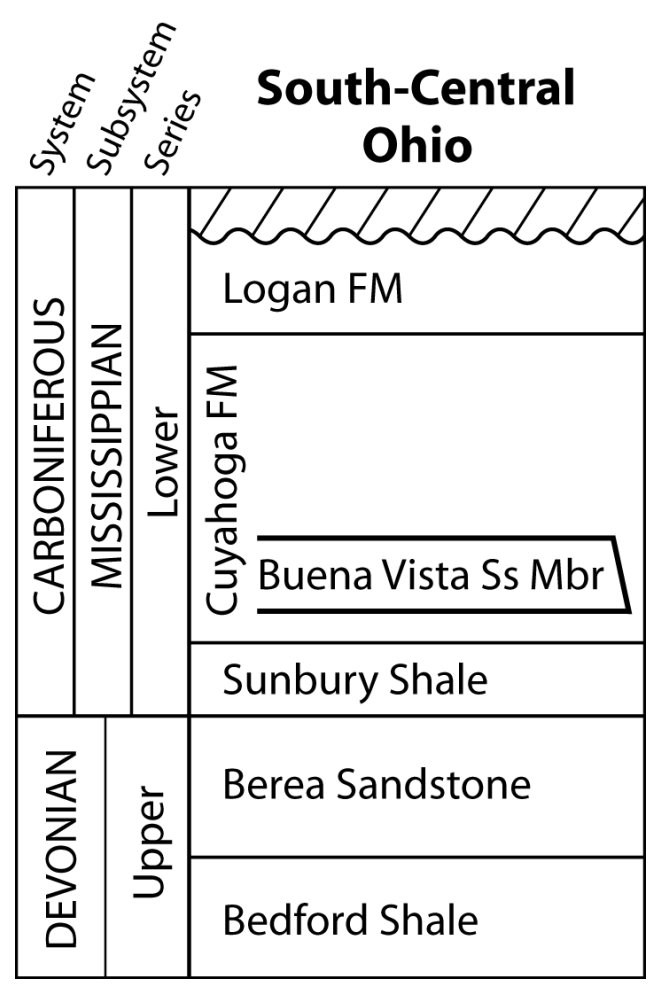

FIGURE 2. Generalized stratigraphic nomenclature chart showing location of Buena Vista Member. Adapted from Hull, Larsen, Slucher 2004.

\section{PUBLISHED NOMENCLATURE}

The Buena Vista Member has been referred to by several different names. When quarried from Waverly, Pike County, Ohio, the Buena Vista Member was referred to as "Waverly stone" (Waverly... 1892); when quarried at Otway, Scioto County, Ohio, as "Otway sandstone"; and when quarried from McDermott, Scioto County, Ohio as "McDermott stone" (Hyde 1953). Some quarries added color descriptors to the name. For instance, the Buena Vista Member from the village of Waverly, was also known as a Waverly brownstone because of its dark color (Orton 1884).

Circa 1880, the Buena Vista Member was mainly referred to in quarry terms as a freestone. In 1884, Hawes et al. (1884) referred to all the quarried sandstone from south-central Ohio as "Waverly Freestone" or "Ohio Freestone." It was this quality, allowing the stone to be cut in any direction without preferential splitting, that made the Buena Vista Member very sought after for sculpted uses such as trim work and laundry tubs. Today the Geological Survey refers to the rock in the Buena Vista Member as simply a sandstone (United States Geological Survey 2016).

In the early geologic literature, all of the then known Mississippian rocks of Ohio, from the Bedford Shale up to the Sharon Formation (then known as "the Conglomerate"), were grouped into the "Waverly sandstone series" (Briggs 1838; Herrick 1891; Wilmarth 1925). Thus, prior to 1900 the terms "Waverly," "Waverly Brownstone," or "Waverly Quarry System" were commonly used in reference to all sandstones in south-central Ohio (for example, Orton 1874; Hawes et al. 1884). As the geology was refined by further mapping, the terminology continued to change from Waverly System (Orton 1874), to Waverly Group (Hawes et al. 1884), and Waverly Series (Hawes et al. 1884). Even in Kentucky, equivalent beds were once referred to as the "sandstone of the Waverly Period" (Kentucky Geological Survey 1876). Around 1900 the terminology changed again, and the use of the term Waverly was abandoned.

Orton (1874) first used the term "Buena Vista" to represent all of the rock for 50 feet above the "Berea shale" (today the Henley Member of the Cuyahoga Formation); that is the bottom 50 feet of the Cuyahoga Formation, which included the thick economic sandstone layers quarried at the village of Buena Vista. He (Orton 1874) qualified this upper limit as arbitrary since there was no "convenient superior limit.” Later Orton (1884) and then Prosser (1902) 
began to further limit the Buena Vista to just the "city ledge" as introduced by Locke (1838)(Fig. 3). Locke (1838) had applied the term "city ledge" to a set of thick layers of Buena Vista Member, cropping out as a single ledge at Rockville, Ohio (1 mile southwest of Buena Vista). He named it the "city ledge" as it was quarried and shipped solely to the city of Cincinnati, Ohio- the primary market at that time (Locke 1838; Orton 1884; Hyde 1953).

These descriptions of only the bottom 50 feet or just the "city ledge" excluded many of the important quarriable ledges of Buena Vista Member being worked a distance to the north and west of Buena Vista. Despite the appearance of uniform horizontal beds within a single quarry, the Buena Vista Member lacks a distinct single bed or group of beds that can be traced over a long distance. Although it could be traced to other quarries nearby, only similar but not identical layers were found at differing elevations farther away. Schumacher et al. (2013) noted that a "localized vertical and horizontal variability" is a diagnostic feature of the Cuyahoga Formation in general. Bownocker (1915) reported the elevation of the Buena Vista Member to increase in elevation from Orton's original 50 feet to as much as 150 feet above the base of the Cuyahoga Formation (cf. Hyde 1953;
Stout 1944). What was termed the Buena Vista not only varied in position from the base of the Cuyahoga Formation but also varied in thickness and number of layers. The Buena Vista Member is comprised of numerous beds that become thinner bedded and more shaly to the south and north of the type locality (cf. Bownocker 1915). Orton in 1874 noted that the Buena Vista thinned out north and east. And Hyde $(1915 ; 1953)$ based on a section he described in the hills of Vanceburg, Kentucky, described the Buena Vista Member as varying in quality, thickness and structure, and that it was more shaly and variable to the north and south of Scioto County. He said, "the number of component beds increased father east ... and northward" and that "its beds become more shaley and worthless" (Hyde 1915).

This change in the elevation and shale content seemed to challenge early geologists who were trying to piece together the stratigraphy from scattered surface exposures, and thus led to several inconsistencies in the early literature (cf. Orton 1874, 1884; Prosser 1902; and Prosser and Cumings 1904). Hyde (1953) and Stockdale (1939) discuss the lateral changes in the lithologic characteristic of the Buena Vista that led to many of the inconsistencies that hindered correlation of a single layer to the north and south of Buena

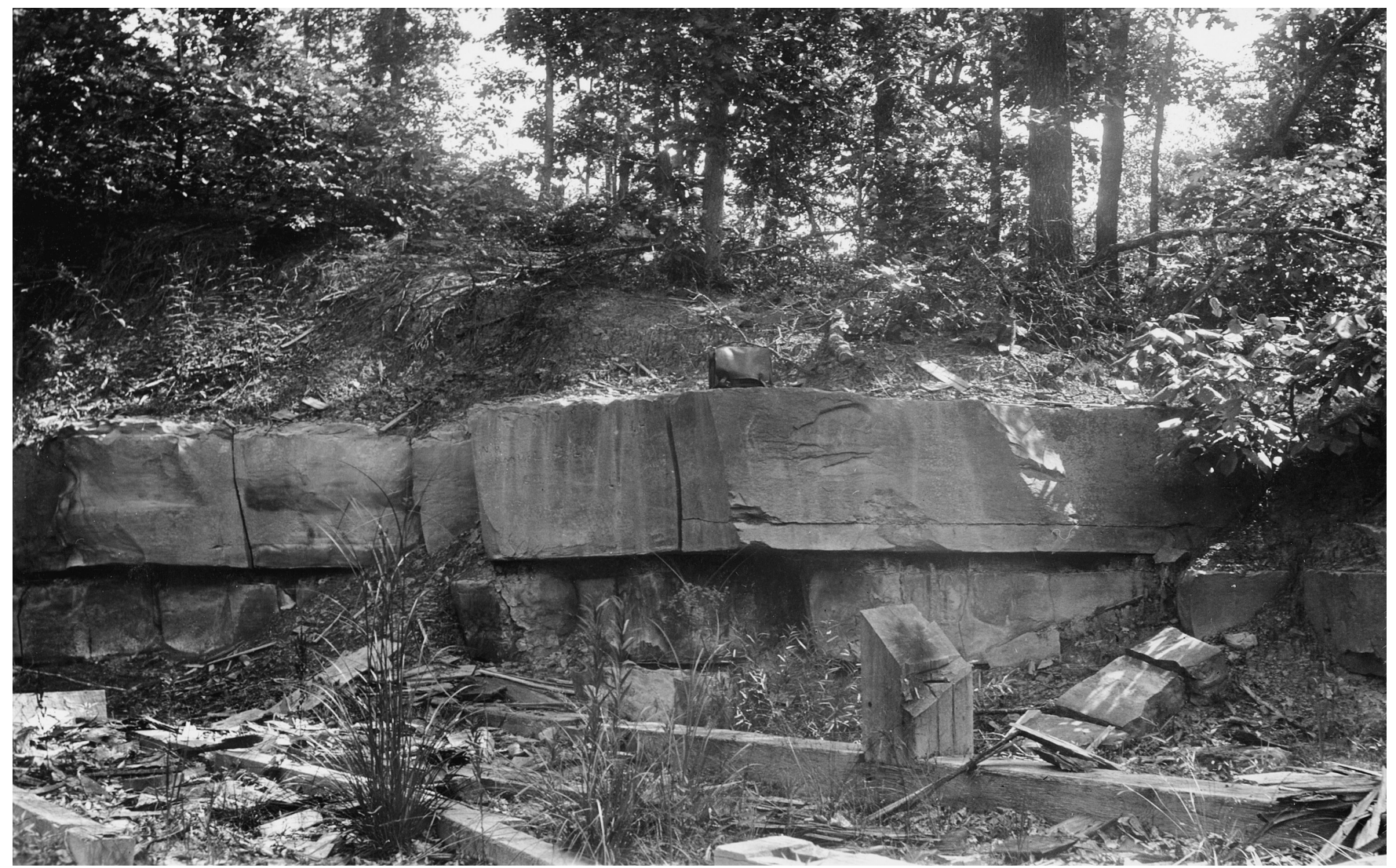

FIGURE 3. Photograph of the City Ledge, Caton Quarry, Little Vastine Creek, Buena Vista, Ohio. Photo by J.E. Hyde 1909, courtesy of the Ohio Department of Natural Resources, Division of Geological Survey. 
Vista. Both Prosser and Cumings (1904) and Hyde (1953) have given good discussions reconciling the inconsistencies in stratigraphic usage of Buena Vista. A measured section of the Buena Vista "city ledge" and associated rocks as compiled from multiple outcrops has been published by Andrews (1871), Bownocker (1915), and Hyde (1953).

Hyde (1953) made an attempt to simplify the stratigraphy by using facies and provinces to trace the extent of similar rocks until the stratigraphy of individual beds could be worked out. Although thinner layers of similar rock type occur at the same stratigraphic position as the Buena Vista Member, no single bed or group of beds similar to the "city ledge" have yet to be traced south of the Ohio River (Stockdale 1939). Nonetheless, Hyde (1915) defined the Vanceburg Facies from the outcrop he described in Vanceburg, Kentucky, and thus placed all the Ohio quarries in the Vanceburg Sandstone Province. Bownocker (1915), Hyde (1915), Butts (1922), and Stockdale (1939) eventually used the Bluestone and Vanceburg facies to equate the stratigraphy of the Buena Vista Member to the quarried freestone layers in Kentucky.

\section{QUARRYING HISTORY}

Quarrying of the Buena Vista Member sandstone in the vicinity of Buena Vista, Ohio, began as early as 1814 (Bownocker 1915). Early travelers such as Maximilian, Prince of Wied (Wied 1841; Hannibal et al. 2009), who traveled through the region in 1834 described mills and stone yards along the canal at Portsmouth that were cutting local sandstone and shaping it for use as building stone. In his 1835 trip through the area, Bradley (1906) also noted the quarrying; as did Koch in the 1840s (1972), who documented gang saws being used to cut 6.5-7.5 centimeters (2.5-3 inches) thick slabs.

In addition to its being a freestone, the Buena Vista Member had several other properties that made it exceptional for quarrying. First, the beds of the Buena Vista Member are uniformly thin and continuous over short distances. The beds range from 2.5 to 183 centimeters ( 1 inch to 6 feet) in thickness, but the majority are under 40 centimeters (16 inches) thick, and have a "remarkable regularity in their lateral extension” (Stout 1944). Second, the layers are interstratified with thin, weak shale parting layers that allow easy separation (Bownocker 1915; Hyde 1953). And third, its durability produced ledges that could be easily worked back into the hillside with minimal overburden removal early in the quarry history (The Ohio . . . 1892). It was these qualities that inspired Locke to refer to the rock face at Rockville as "Belle" or "the Beautify Quarry" (Locke 1838; Bownocker 1915).

Early production of the Buena Vista Member as a building stone used gravity to quarry, mill, and transport the product. The Buena Vista Member crops out as easily accessible ledges with minimal overburden near the banks of the Ohio River. Early excavation and transport relied on gravity to move the bulk material to the mills and markets. At first quarrying took place on large blocks that had naturally cleaved from the ledges and rolled to the base of the hills. Bownocker (1915) reported that "Joseph Moore, who first quarried stone at Buena Vista in 1814, did not work the rocks in place, but the large blocks lying on the slopes or at the foot of the hills." Quarrying subsequently moved to ledges on the hillside from where blocks were first rolled downhill in chutes, then hauled by oxen, haul lines, or cables, dragged on the ground, transported by sleds and then wagons down roads, and then inclined railways to the mills and river docks. Once on the river, barges moved blocks and slabs downstream to markets in Cincinnati and beyond (Stivers 1900). Some of the early mills utilized the gravitational energy of flowing water to run the stone saws (Hannibal et al. 2009). Only at the very end of the 19th century was steam commonly used to run drills, winches, and derricks (cf. The Wardwell ... 1888).

The Buena Vista was in high demand in the 19th century as documented by reports of mill expansions and the operation of numerous gang saws working night and day (The Ohio . . . 1892; Stivers 1900). Maximilian, Prince of Wied (1841; Hannibal et al. 2009) reported seeing 70 saws being used to cut blocks of the freestone for use as building stone, tombstones, and other uses. Similarly to the City Ledge, individual ledges were claimed such as the Trust Company Bank Ledge, also known as the "White Ledge" of Locke (1838), quarried exclusively for Trust Company Bank buildings (Stivers 1900). Demand was so high that some quarry operators cut and shipped to market rock that was still "green," or unseasoned (Orton 1884).

The Buena Vista Member was shipped to many cities around the United States and Canada. Bownocker (1915) reported it having been sold to markets that extended from "Maine to Missouri and from New Orleans to Alberta." Early on, although it was shipped by wagon to cities in Ohio, Kentucky, Virginia, Pennsylvania, and Indiana (Duzan 1880), water and 
railways greatly aided the transportation of the Buena Vista Member to many cities and towns: Cincinnati, Ohio, Louisville, Kentucky, and Evansville, Indiana, on the Ohio River; New Orleans, Louisiana, on the Mississippi; Dayton and Columbus, Ohio, on the Ohio canal system; and later Chicago, Illinois, Detroit, Michigan, Milwaukee, Wisconsin, Wheeling, West Virginia, Mobile, Alabama, Pittsburgh, Pennsylvania, Salem, North Carolina, Baltimore, Maryland, New York, New York, Boston, Massachusetts, and Alberta, British Columbia, on newly formed railways (Orton 1884; Bownocker, 1915; Hyde 1953).

The Buena Vista Member was offered for sale, as documented in advertisements in Stone: An Illustrated Magazine (Waverly ... 1892; Blue... 1892; Freestone 1892) from dozens of quarries at Buena Vista, Portsmouth, McDermott, Rarden, Otway, Henley, Lucasville, Crabtree, Piketon, and Waverly. Geologic Survey reports noted quarry operations at Buena Vista (1814-1909), Carey Run, Portsmouth (1867-1909), McDermott (1894-present), Rarden (1892-1904), Otway (1886-1898), Freestone (1886-1907), and Henley (unknown-1907) in Scioto County, Piketon and Waverly in Pike County, Lithopolis in Fairfield County, and Blacklick in Franklin County (Bownocker 1915; Stout 1944).

Plotting the Ohio quarry locations on a map shows a historic progression echoed in the literature (Fig. 4). The quarries develop first along the banks of the Ohio River and then move up the stream valleys following ledge exposures. Then, quarries opened farther north in the hills along the Ohio and Erie Canal, and finally, by $1880 s-1890$ s, they opened in scattered locations across the outcrop region as new railway lines dominated transportation.

Bownocker (1915) reported that "About 1883 stone from the hills between Rarden and the Scioto River was quarried for use on the railroads." This stone would have been from the quarries in Henley and McDermott that lie near the Norfolk and Western Railroad (Fig. 4). Three years later, in 1886, the quarries at Freestone, and Otway (yet further north) opened (Bownocker 1915). Then, circa 1892, it was reported that "Thirty miles north of Portsmouth on the Scioto Valley division of the Norfolk and Virginia R. R. is [the town of] Waverly, where blue, buff and brown sand and freestone are quarried by the Waverly Stone Company-a company recently organized" (The Ohio . . . 1892). A year later, an advertisement for the Reitz \& Co. says they are "Located on B. \& O.
[Baltimore and Ohio], S W. [Ohio Southwestern], N \& W. [Norfolk and Western], C., P. \& V. [Cincinnati, Portsmouth \& Virginia] and C. \& O. [Chesapeake \& Ohio] Railways; also shippers via Ohio river." (Portsmouth . . . 1893). Then, in 1898, an article in the Portsmouth Blade about the M. Coe \& Sons quarry at the village of Freestone promoted their own siding on the Cincinnati, Portsmouth \& Virginia Railroad (M. Coe . . 1898).

In combination with the selling of unseasoned "green" stone and the increasing use of concrete, quarries mining the Buena Vista Member began to close (Bownocker 1915). Eventually, profitability was diminished by the slow method of waterway transport and increasing overburden removal once the initial ledge face was quarried back into the hillside (Hyde 1953). In 1904, the last company in Buena Vista, the Buena Vista Freestone Company, went into receivership and, in 1909, closed (Bownocker 1915). By 1914 all of the quarries except those at McDermott had closed (Hyde 1953). The Buena Vista Member has been continuously quarried in Ohio by the Waller Brothers Stone Company at the current McDermott quarry (previously an Inskeep Quarry). That quarry operated under different names from 1905 to 1913

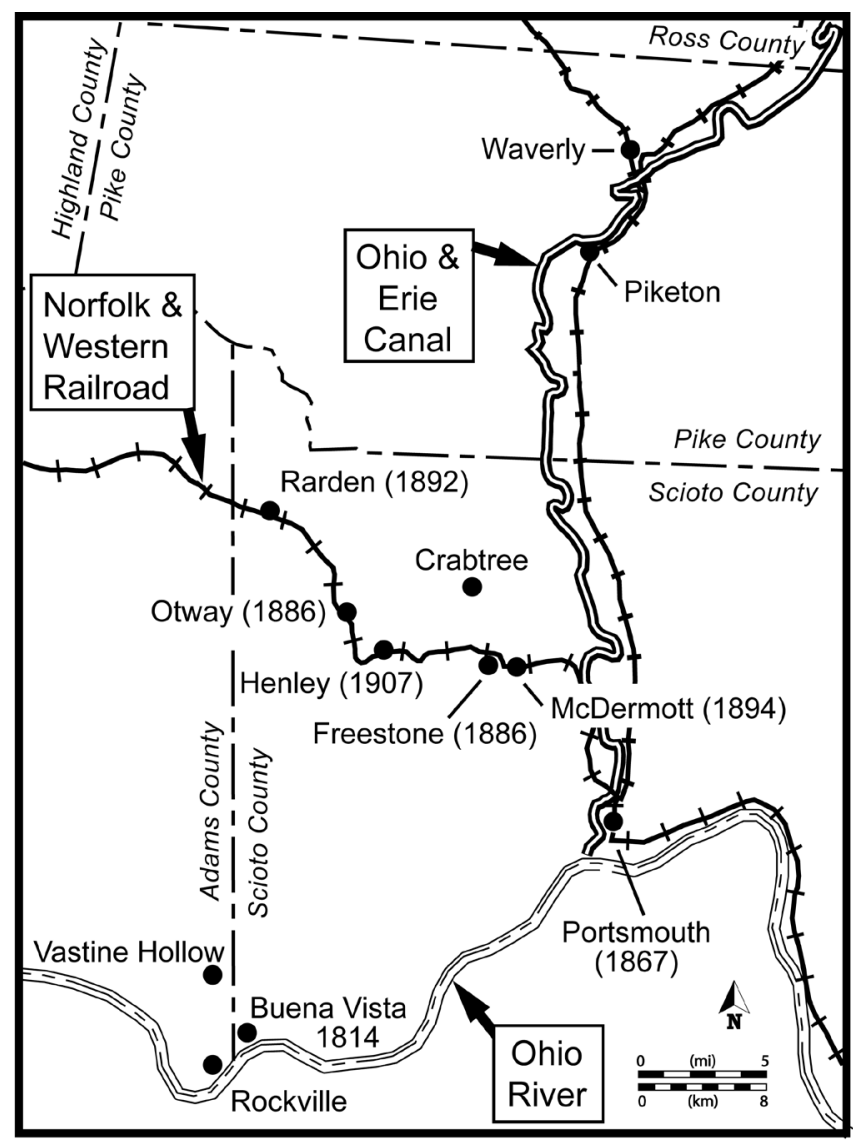

FIGURE 4. Map showing location of historical quarry towns in relation to the Ohio River, Ohio \& Erie Canal, and railway lines. 
(Wolfe and Stucker 2014). According to Frank Waller (via personal communication in July, 2008), its main use was for building stone (walls, ashlar, and trim), but in the last decades of the twentieth century, the majority of quarried stone was used for laboratory tables, impregnated to produce an impervious surface.

\section{ECONOMIC USES}

The uniform properties of the Buena Vista Member that made it easy to cut and carve made it desirable for a variety of uses. As noted in the 10th Census Report of 1880 (Batchen 1884), the Buena Vista Member was used for canal structures, buildings, building trim, laboratory tables, fence posts (Fig. 5), and sidewalks. It was also used for curbstones, abutments, cemetery vaults, bridges, retaining walls, foundations, rip pap, flagging, capitals, ax-bits, whetstones, stair treads, stair platforms, black boards, laundry tubs, urinal partitions, and furnace hearths (Locke 1900; Stout 1944; Hyde 1953).

Many early structures that used the Buena Vista Member are still standing (Table 1). Buena Vista Member was used for the columns of St. Peter in Chains Cathedral (1845) and the trim of the Plum Street Temple (1866) in Cincinnati, Ohio, and the trim of the Trinity United Methodist Church (1866) in
Evansville, Indiana. All three buildings are still standing today. It can also be found comprising large sections of the Basilica of St. Josaphat (1901) in Milwaukee, Wisconsin, and the Roebling Suspension Bridge (1868) across the Ohio River in Cincinnati, Ohio.

After the great fire in Chicago of 1871, several store fronts were constructed of the Buena Vista Member because it conformed to new fire codes. These structures include, amongst many others, the Chamber of Commerce on the southeast corner of Washington and LaSalle, the four-story Metropolitan Block on the northwest corner of Randolph and LaSalle streets, the Union Trust Co.'s block, and the Merchant Insurance Building, a five-story commercial block on the corner of Washington and LaSalle streets (Destruction . . . 1891). Batchen (1884) also listed the Dore city block and other store fronts as being made with stone from the Buena Vista Member. Several of these are known to still exist, for example, the Holden Block, a fourstory Italian style commercial loft that was constructed in 1872. It was recognized as a historical landmark building (Commission on Chicago Landmarks 2011) and has since been newly renovated.

Completed in 1901, the Basilica of St. Josaphat in Milwaukee, Wisconsin, is a remarkable example of reuse of a building stone (Fig. 6). The Buena Vista

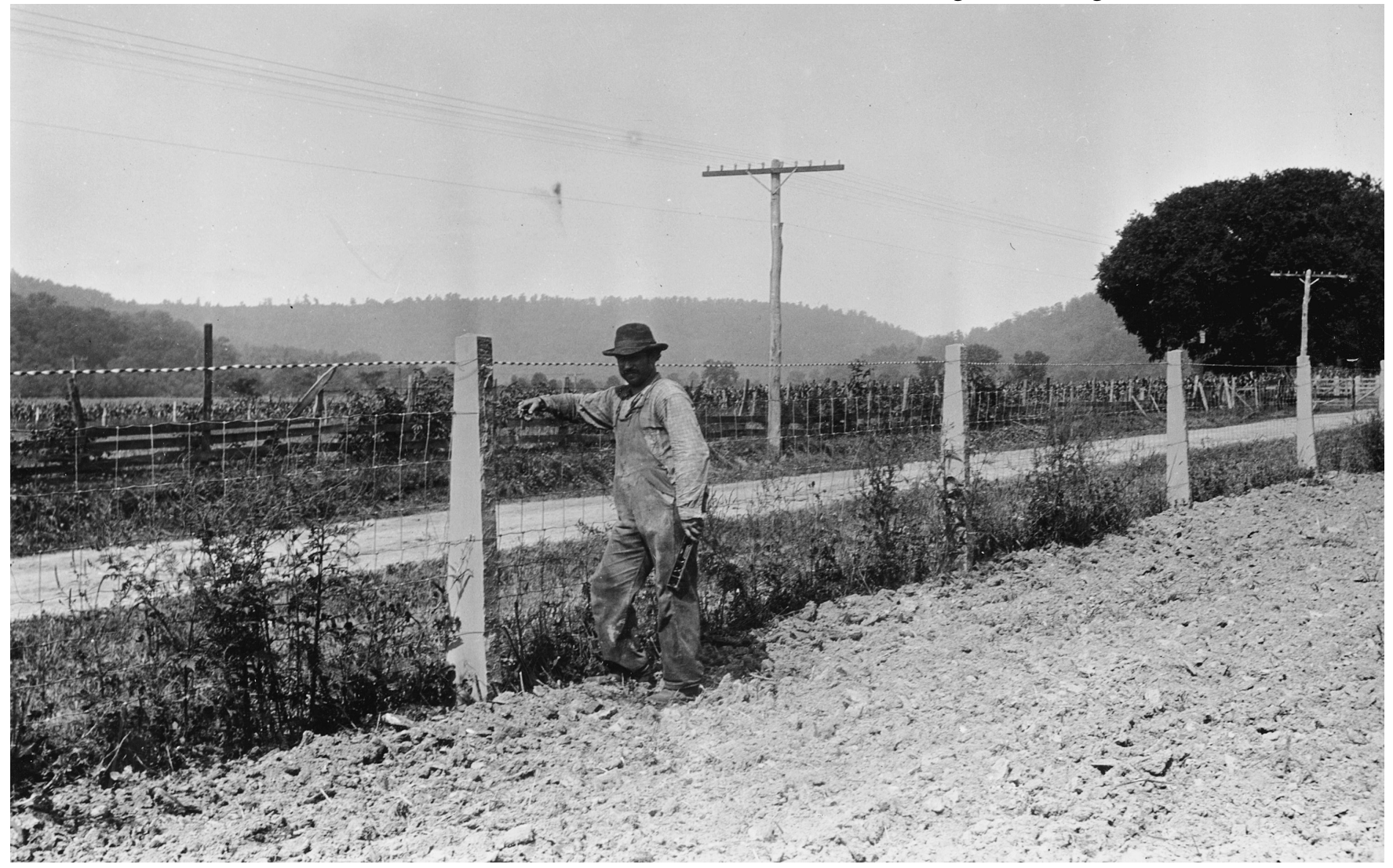

FIGURE 5. Photograph showing fence posts made from Buena Vista Member sandstone, Taylor Stock Farm, Rarden, Ohio. Photo by J. E. Hyde 1909, courtesy of the Ohio Department of Natural Resources, Division of Geological Survey. 


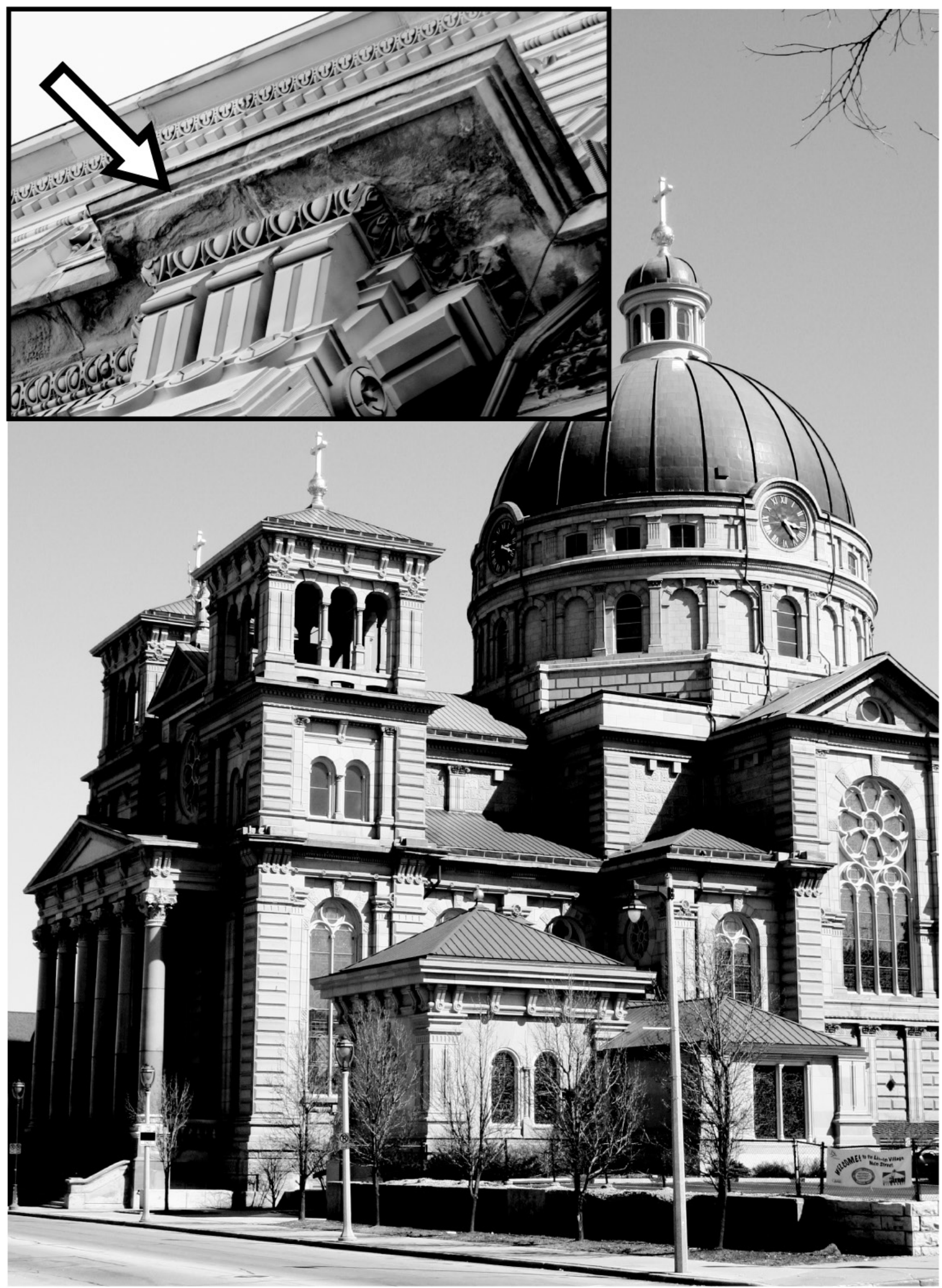

FIGURE 6. Photograph of St. Josaphat Basilica constructed with stone from the Buena Vista Member. April, 2008 photo. Inset photograph showing weathering on the underside of the overhang (arrow). April, 2008 photo. 
Table 1

Selected structures in Ohio and other states made with

Buena Vista Member sandstone from Ohio quarries.

\begin{tabular}{|c|c|c|c|}
\hline Location & Structure-Part made of Buena Vista & $\begin{array}{l}\text { Date } \\
\text { Finished }\end{array}$ & Source \\
\hline Athens, $\mathrm{OH}$ & courthouse: parts of exterior & 1880 & Orton, 1884 \\
\hline Benton, $\mathrm{OH}$ & Eager Inn: exterior & c. 1797 & Wolfe, 2003 \\
\hline Buena Vista, $\mathrm{OH}$ & sidewalks and buildings: steps, etc. & $1800 s$ & our observations \\
\hline Cincinnati, $\mathrm{OH}$ & Covenant First Presbyterian: trim & 1875 & Hannibal and Davis, 1992 \\
\hline Cincinnati, $\mathrm{OH}$ & locks: lockstone & $1830 \mathrm{~s}$ & Lapham, 1833 \\
\hline Cincinnati, $\mathrm{OH}$ & $\begin{array}{l}\text { street pavement, various parts of buildings, } \\
\text { and other uses }\end{array}$ & $1800 \mathrm{~s}$ & $\begin{array}{l}\text { Hawes and others, 1884; } \\
\text { Bownocker, 1916; } \\
\text { Hannibal and Davis, } 1992\end{array}$ \\
\hline Cincinnati, $\mathrm{OH}$ & Plum Street Temple: trim & 1866 & Hannibal and Davis, 1992 \\
\hline Cincinnati, OH & Roebling Suspension Bridge: piers & 1867 & Hannibal and Davis, 1992 \\
\hline Cincinnati, $\mathrm{OH}$ & $\begin{array}{l}\text { Spring Grove Cemetery: } \\
\text { various structures and monuments }\end{array}$ & $1800 s$ & our observations \\
\hline Cincinnati, $\mathrm{OH}$ & $\begin{array}{l}\text { St. Peter in Chains Cathedral: } \\
\text { exterior columns }\end{array}$ & 1845 & Hannibal and Davis, 2002 \\
\hline Cleves, $\mathrm{OH}$ & canal tunnel: tunnel entrance & early 1840 s & Hannibal and Davis, 2007 \\
\hline Columbus, OH & Orton Hall: columns & 1893 & $\begin{array}{l}\text { Melvin and McKenzie, } \\
1992\end{array}$ \\
\hline Columbus, $\mathrm{OH}$ & buildings: exterior & $1800 s$ & Hawes and others, 1884 \\
\hline Dayton, $\mathrm{OH}$ & $\begin{array}{l}\text { Woodland Cemetery: } \\
\text { obelisks and other grave monuments } \\
\text { (moved to this site from an earlier cemetery) }\end{array}$ & pre-1840 & Sandy, 1992 \\
\hline Dayton, $\mathrm{OH}$ & buildings: trim & $1800 s$ & Hawes and others, 1884 \\
\hline North Bend, OH & Congress Green Cemetery: gravestones & early 1800 s & Hannibal and Davis, 2007 \\
\hline Portsmouth, $\mathrm{OH}$ & Public Library: exterior & 1906 & $\begin{array}{l}\text { library staff; } \\
\text { our observations }\end{array}$ \\
\hline $\begin{array}{l}\text { Portsmouth, OH, } \\
\text { area }\end{array}$ & Ohio \& Erie Canal: locks & $1820 s$ & Hannibal, 1996 \\
\hline Chicago, IL & $\begin{array}{l}\text { Holden and Dore city blocks, etc. } \\
\text { residences and storefronts }\end{array}$ & $1800 \mathrm{~s}$ & Hawes and others, 1884 \\
\hline Chicago, IL & Merchants Building: exterior & late 1800 s & Hawes and others, 1884 \\
\hline Chicago, IL & $\begin{array}{l}\text { Customs House and Post Office: exterior } \\
\text { (stone reused for Basilica of St. Josaphat) }\end{array}$ & 1879 & Hawes and others, 1884 \\
\hline Evansville, IN & Trinity United Methodist Church: trim & 1866 & $\begin{array}{l}\text { Hannibal and others, } \\
\text { 2008; our observations }\end{array}$ \\
\hline $\begin{array}{l}\text { Evansville, IN, } \\
\text { and other cities } \\
\text { and towns along } \\
\text { the Ohio River }\end{array}$ & curbs: curbstone & $1800 s$ & Hawes and others, 1884 \\
\hline Indianapolis, IN & buildings: exterior & $1800 s$ & Hawes and others, 1884 \\
\hline
\end{tabular}


Table 1 (cont.)

Selected structures in Ohio and other states made with Buena Vista Member sandstone from Ohio quarries.

\begin{tabular}{|c|c|c|c|}
\hline Location & Structure-Part made of Buena Vista & $\begin{array}{l}\text { Date } \\
\text { Finished }\end{array}$ & Source \\
\hline Louisville, KY & stone buildings: exterior & $1800 \mathrm{~s}$ & Hawes and others, 1884 \\
\hline Grand Rapids, MI & buildings: exterior & $1800 s$ & Hawes and others, 1884 \\
\hline New Orleans, LA & residence: exterior & late 1800 s & Bownocker, 1915 \\
\hline New York, NY & buildings: exterior and miscellaneous uses & 1800 s & Julien, 1884 \\
\hline Memphis, TN & building: storefront & $1800 s$ & Hawes and others, 1884 \\
\hline Baltimore, MD & Johns Hopkins Hospital: exterior & 1889 & Bownocker, 1915 \\
\hline Wheeling, WV & sidewalks: paving & $1800 s$ & Hawes and others, 1884 \\
\hline Milwaukee, WI & $\begin{array}{l}\text { Basilica of St. Josaphat: exterior } \\
\text { (reuse of stone from Chicago Customs } \\
\text { House and Post Office) }\end{array}$ & 1901 & our observations \\
\hline Milwaukee, WI & Pope John Paul II Pavilion & 2000 & our observations \\
\hline Washington DC & Arts and Industries Building (1881) & $\begin{array}{l}\text { restoration } \\
2013\end{array}$ & $\begin{array}{l}\text { Livingston, Grissom, } \\
\text { Aloiz, } 2015\end{array}$ \\
\hline
\end{tabular}

Member sandstone in this building had originally been used to construct the Post Office and Customs House in Chicago in 1880. The Post Office, which stood from 1880 to 1895 , was one of many Chicago stone structures erected after the fire of 1871 . It was constructed from Buena Vista Member quarries in the town of Freestone, Ohio (Merrill 1886). After some structural problems were found, it was carefully dismantled and transported by rail to Milwaukee for reuse to build the Basilica (Batchen 1884; Wolfe 1996; Glastetter and Switanowski 2002). A building across the street from the Basilica also has a front made from the Buena Vista Member. It was constructed about the same time as the Basilica, and could possibly be from the same Post Office material that was left over from the construction of the Basilica.

The stone used for the Basilica is today in generally good shape, and the ornamental details carved by the stonemasons is preserved, including chisel-drafted margins, drovework, and ornate carved details. However, time and weathering have revealed problems. Batchen (1884) had observed problems with pyrite and with scaling along drovework in stone used in Chicago's Customs House back in 1884. Today, pyrite nodules can be seen weathering out of the cut face in a few places, and some portions of the stonework have had to be replaced since the Basilica's construction. Despite this, a new addition to the Basilica of St. Josaphat, the
Pope John Paul II Pavilion, was recently added and dedicated in 2000. It was constructed with stone from the Buena Vista Member recently quarried from the McDermott, Ohio, area quarries (Frank Waller via personal communication in July 2008). This same quarry also produced stone for repairs made to the Arts and Industries Building on the National Mall in Washington DC in 2013 (Livingston et al. 2015). Since another famous Ohio building stone, the Euclid Bluestone, was not available, the Buena Vista was used to replace the deteriorated bottom courses of stone work at the entrance of the building.

\section{Petrology}

\section{ROCK DESCRIPTION}

The Buena Vista Member sandstone from Adams and Scioto counties is by average grain size a coarse siltstone. Samples from the McDermott and Buena Vista quarries $(n=6)$ contain well size-sorted grains of coarse-silt size, between 32 and 75 micrometers (averaging 50 micrometers, $\mathrm{n}=40$ ). By the UddenWentworth scale (Wentworth 1922; see Walker and Cohen 2006) this range spans the coarse silt (31-63 micrometers) and just enters the very-fine sand (63-125 micrometers) classification. The average grain has an angular (1.5) roundness, and a subprismoidal (1.5) to spherical (3) sphericity (Walker and Cohen 2006). The rock is clast-supported with cubic packing, 
and displays low to moderate compaction. Almost all framework grain contacts are blunt (no overgrowths, embayed, or impinging contacts), and only a few detrital(?) biotite grains are slightly bent. The Buena Vista Member has a pervasive microporosity through the skeletal remains of weathered grains and through clay and iron oxide cement-filled pore spaces. And all the grains are cemented with both clay and iron oxide as noted by Stout (1944). Under plain polarized light of a thin section, the rock has a very "dirty" almost greywacke appearance that at first glance appears to be matrix supported, but it is not a pseudomatrix.

Mineral identifications, obtained from a Nikon Eclipse E400Pol polarizing microscope and a Philips XRG3100 $x$-ray powder diffractometer (XRPD), show that the Buena Vista Member is composed dominantly of monocrystalline quartz with accessory lithic (shale and chert) fragments, plagioclase feldspar, muscovite, biotite, chlorite, iron oxide, pyrite, ilmenite, titanite, and zircon.

In thin section, detrital phyllosilicate minerals and a majority of elongate quartz grains are all aligned parallel to bedding (Fig. 7). In hand specimen at 10x magnification, abundant muscovite grains can be seen as silver dots lying on bedding planes. Low compaction and lack of impinging grain contacts indicates that this aligned grain orientation is depositional and can be used to find the orientation of bedding when there are no other markers.

Petroleum was an impurity that detracted from the use of Buena Vista Member as a decorative building stone, but it was only briefly mentioned in early reports. In 1871, Andrews mentions "oil springs" emanating from the black shale below the Buena Vista Member. Although petroleum has been recovered, drillers report the sand as dominantly a gas producer (Stout 1944). Orton (1884) specifically reported that the petroleum, where present, was a serious problem that marred the appearance of the quarried stone, which limited its use to "rough heavy work" such as rip rap and bridge abutments. In fact, Roebling (1867), engineer of the Brooklyn Bridge, preferred and used this petroleum impregnated Buena Vista Member for the foundation courses of the Roebling Suspension Bridge.

Colors of the Buena Vista Member are blue, buff, gray and brown as recorded by advertisements (Waverly ... 1892; Blue ... 1892; Otway . . 1893; Portsmouth ... 1893) and blue, gray, yellow, and brown by quarry reports (Bownocker 1915; Stout 1944). This compares well with the colors of our collected samples: blue

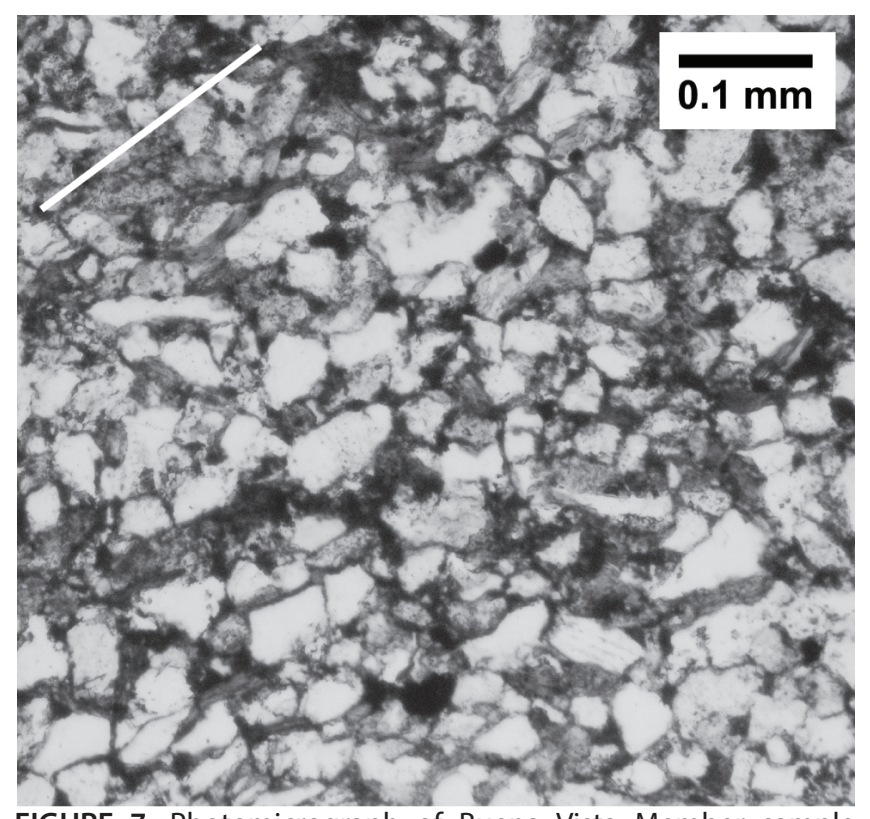

FIGURE 7. Photomicrograph of Buena Vista Member sample CMNH 8946A, showing general texture and orientation of phyllosilicate grains parallel to bedding (white line in upper left).

gray, yellowish buff, and brown. The rock's color is a blue gray when freshly quarried, and weathers to buff and even brown with time and exposure (Hawes et al. 1884; Bownocker 1915; Stout 1944). Even though both are colored blue when first exposed, this darker weathered color of the Waverly distinguished the stone quarried in these layers from the classic buff colored stone from Buena Vista quarries in the south. In fact the Pike County stone was thus marketed "by Morris Richey, of Waverly ... [as] Waverly brown stone" (Orton 1874).

\section{Weathering and Case Hardening}

When the Buena Vista is exposed to the atmosphere the surface grains commonly darken in appearance to a brownish color. Orton (1874) noted that "the brown color for which it [the Buena Vista] is so justly admired is not a natural, but a derivative color, formed from the conversion of a notable quantity of protoxide of iron $\left[\mathrm{FeO}_{2}\right]$ into sesquioxide $\left[\mathrm{Fe}_{2} \mathrm{O}_{3}\right]$."

Specimens of Buena Vista Member from Vastine Hollow, Adams County (CMNH 8963) have a highly weathered surface with a dark-golden-brown color. When freshly broken normal to this brown-weathered surface, the break reveals that this coloration does not penetrate very deep (Fig. 8). Several polished sections cut in cross section to the exposed surface of these brown specimens display a rind of iron oxide that penetrates on average $3 \mathrm{~mm}$ into the rock. In thin section, this rind is a pervasive dense precipitation of iron oxide that reduces the porosity to near zero at the rock's exposed 
surface, thus armoring the surface in a process known as case hardening (Conca and Rossman 1982).

This observation agrees with historical reports that the Buena Vista stone does "harden with age" (The Ohio 1892). It was noted by Batchen in 1884 that the stone commonly rusts when it is in contact with iron, denoting an oxidizing quality of the stone. He wrote that "The laying of a wet chisel or any piece of wet iron on the stone for a few hours is sufficient to cause a similar stain" (Batchen 1884).

\section{Fossils}

The Buena Vista Member contains a variety of fossils (Willis 1996). These include productid brachiopods and the ichnofossil Zoophycos (known as Spirophyton in the earlier literature, e.g. Andrews (1871) and Hyde (1953). The Zoophycos have been used to distinguish the Buena Vista Member from other fine-grained tan sandstones of Ohio (Hannibal 1995). Zoophycos tubes and spreiten are obvious and easily recognized in cut rock surfaces (Fig. 9). Some of the Zoophycos are filled or lined with dark-gray clay that helps distinguish them (Hannibal 1995). However, with time this clay weathers out leaving hollow voids in the stone.

\section{Depositional Environment}

The Buena Vista Member has been interpreted by Hannibal and Davis (1992) as having been deposited as marine-shelf sands and muds based on trace fossils like Zoophycos. Chaplin $(1980,1982)$ interpreted the environment of deposition of the correlated Farmers Member from Bouma sequences and trace fossils as proximal turbidites in a prograding deltaic complex into a starved basin. Demases and McPherson (1984)

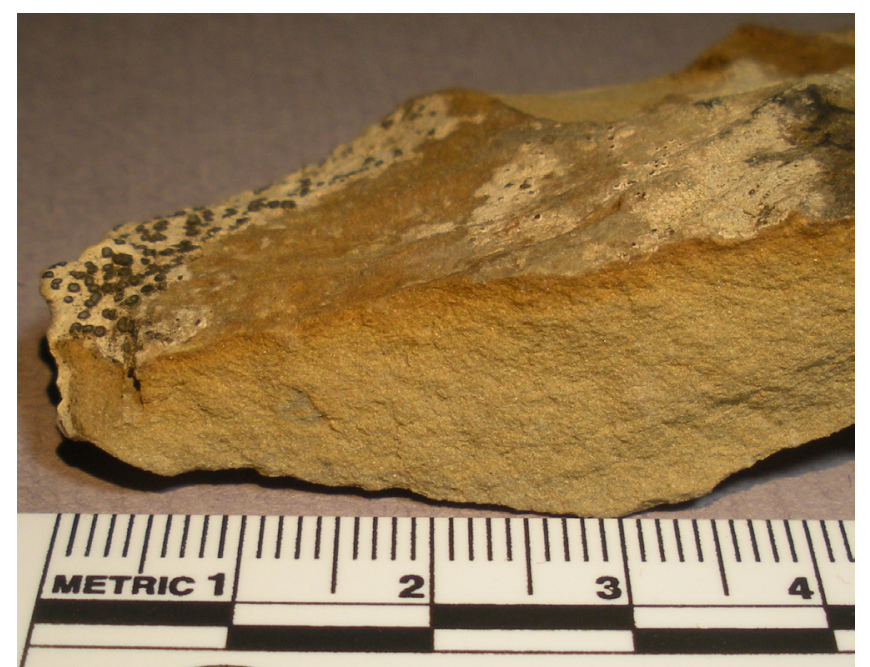

FIGURE 8. Photograph of brown Buena Vista Member, sample CMNH 8963, broken normal to the weathered surface showing the depth of brown iron oxide weathering. similarly described it as a proximal to distal deltaic turbidite sequence at the toe of the delta based on lithofaces associations. More recently, Lierman et al. (1992) interpret the correlative Farmers Member as proximal turbidites with intercalated hemipelagic muds, and Hannibal (1995) further refined the deposit as turbidites or storm deposits based on the repetitive nature of the sandstone and shale couplets and sedimentary structures within the sandstones.

\section{BUILDING STONE CHARACTERISTICS Durability as a Building Stone}

The qualities of the Buena Vista Member that made it desirable for so many uses can be explained by the petrography. For example, the angularity of grains in the Buena Vista Member provide a high friction surface good for walkways as noted by Orton because it "always gives foothold" (Orton 1884; Bownocker 1915). But it is the freestone nature of the rock that is the result of near equant grains (equal in all three axial dimensions) and uniform cementation that makes it a nearly isotropic material, despite the alignment of a few inequant grains parallel to bedding. The stone's high porosity, and low permeability, restricts the flow of water into the Buena Vista Member, but allows for drying. Over time, the iron oxide case hardening additionally reduces water absorption on exposed surfaces. But ultimately, the uniform clay and iron cementation gives the Buena Vista Member its good durability, even in wet conditions.

Despite this, the Buena Vista Member has been known to crumble, as reported by Batchen in 1884, who discusses spalling and iron pyrite spots in the Chicago Customs House, which can also be currently seen on the underside of overhangs at the Basilica of St. Josaphat (Fig. 6 inset). The deterioration of some blocks may be the result of the length of time it was seasoned or the mixing of material quarried from different layers. Over the quarrying history of the Buena Vista, the stone was not quarried from one single bed, but from many different layers within the stratigraphic section. Some layers had better quality than others, but all having the same general field and hand-sample characteristics. Howe (1908) stressed that the choosing of material "needs careful and conscientious selection and suitable seasoning."

The zoophycoids, especially their clay-filled marginal tubes, weather out leaving hollow molds (Fig. 9A). However, Hannibal (1995) looked at the role of trace fossils on weathering, and showed that the occurrence 


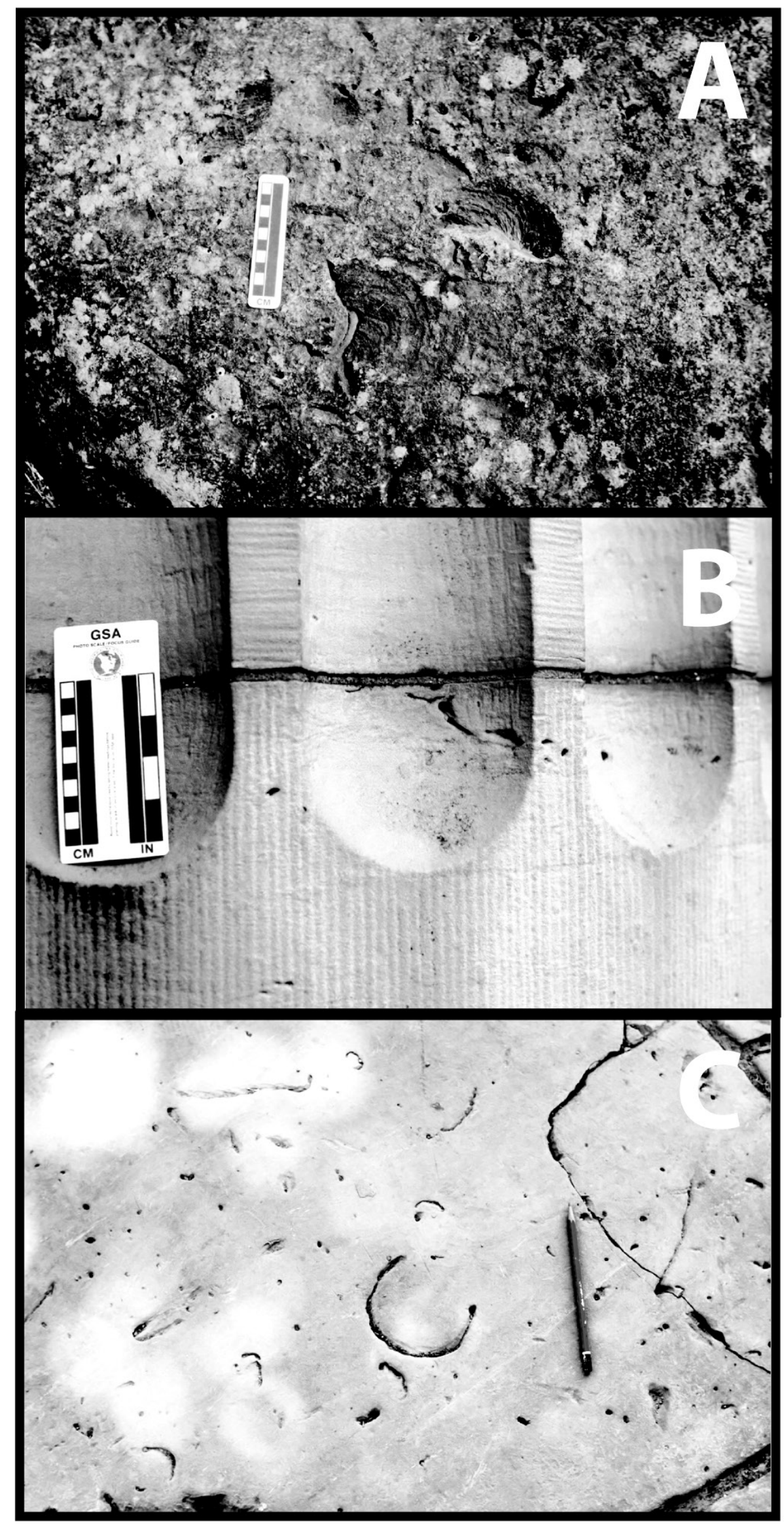

FIGURE 9. A) Photograph of zoophycoids in Buena Vista Member used in canal lock at West Portsmouth, Ohio. 1995 photo. B) Photograph of the columns of St. Peter in Chains showing trace fossils. April, 2008 photo. C) Photograph of a sidewalk in the town of Buena Vista showing hollow molds of weathered-out productid brachiopod. Pencil for scale. 2008 photo. 
of these fossils does not hinder the stones durability. The stone around the hollow tubes in the columns at St. Peter in Chains Cathedral (Fig. 9B), over 150 years old, is still in good quality. This quality is also seen in the blocks of the canal lock at West Portsmouth (Fig. 9A), and in the sidewalks in Buena Vista (Fig. 9C). Bownocker (1915), over one hundred years ago, said "the stone in these locks is now in the main in good condition after 80 years of the severest tests." Bownocker (1915) also said "while these holes injure the appearance they do not mar the rock in other respects." Even today, a small amount of the Buena Vista Member sandstone with hollow-tube trace fossils was used in the newly constructed Pope John Paul II Pavilion at the Basilica of St. Josaphat.

\section{Proveniencing Historical Material}

In the proveniencing of Buena Vista Member sandstone, the size of grains can help distinguish it from the similarly colored Berea Sandstone. The Berea Sandstone quarried for building stone comes dominantly from northern Ohio where the grains are fine- to medium-sand sized (Hannibal et al. 2006). However the grain size of the Berea in southern Ohio tends to be finer than in northern Ohio (Schumacher et al. 2013). Samples of Berea Sandstone from the Amherst quarry show dominantly well-rounded grains (Churcher et al. 1991); however, some fine-grained samples show angular grains (Foreman and Thomsen 1940). Nonetheless, Hannibal (1995) was able to distinguish the homogeneous Buena Vista Member from Berea Sandstone based on the Berea's large grain size and distinct bedding with some distinction discerned from the angularity of grains.

\section{CONCLUSION}

The Buena Vista Sandstone Member of the Mississippian Cuyahoga Formation is a nationally important historic building stone that was quarried in abundance and used for ornate trim and entire buildings in cities scattered over more than half of North America. This material played a significant role in the rebuilding of the City of Chicago after the 1871 fire that destroyed much of the cityscape. Although few buildings from this era still survive, many of those that did are now historical landmarks, almost 150 years after their construction.

An important economic resource throughout the 19th century, this homogeneous freestone occurs in thin, uniform, and laterally continuous layers with interstitial clay, perfect for ease of separation and cutting. Petrographic analysis shows that the Buena Vista Member is a poorly-compacted, clast-supported siltstone composed of angular grains cemented with iron oxide and clay. The Buena Vista Member was a near perfect natural stone resource in terms of ease of quarrying and workability, and proximity to transportation routes, at a time in history when quality stone was in high demand for building construction and consumer products such as tubs and fence posts. Rare productid brachiopods, ichnofossils, petroleum, and iron staining do not detract from the stone's architectural qualities. The historical trends in quarrying during the time when the Buena Vista was mined show a progression from mainly using brute force and gravity to extract material from hillsides and dragged to be used locally, and then hauled by wagons, rafts on rivers, barges on canals, and then early railroads for eventual shaping and sale in markets around the United States and Canada. It was highly advertised and sought after by architects and manufacturers nationwide. Documented herein are only a small number of buildings still standing that used Buena Vista, but there is a great potential for the existence of this stone in numerous historical buildings yet to be rediscovered. This stone is still available and its unique properties make it a potentially useful natural material even today.

This research describes new insight as to how this stone can be identified in hand sample in the field, such as detrital phyllosilicate grains aligned parallel to bedding that are easily distinguished as silver flecks with a hand lens. The Buena Vista Member has been published under dozens of names, such as "Waverly" and "Brownstone" since before it was first described by Orton in 1876 at Buena Vista, Ohio. And this economically valuable layer mentioned in the old literature is actually several layers at different horizons as hinted to by Prosser and Hyde in their later publications. Thus, this research also cites numerous historical documents and scientific publications, which are cited herein to clarify the geologic descriptions and quarrying history.

\section{ACKNOWLEDGEMENTS}

We thank the Department of Geosciences at the University of Akron for use of their Phillips x-ray diffractometer; the Ohio Department of Natural Resources, Division of Geological Survey for permission to reproduce images of the City Ledge and 
Buena Vista Member fence post by J.E. Hyde; and to Cary Maleu, Director of Environmental Services, the Basilica of St. Josaphat, for samples, access, and assistance in examining the stonework.

\section{LITERATURE CITED}

Andrews EB. 1871. Report of progress in the Second District, part II. Columbus, OH: Ohio Division of Geological Survey. p. $55-142$.

Batchen JSF. 1884. Chicago, Illinois. In: Hawes GW, et al. Report on the building stones of the United States and statistics of the quarry industry for 1880. U.S. 10th Census. p. 294-297.

Blue and buff freestone. 1892. Stone. 5:xv.

Bownocker JA. 1915. Building stones of Ohio. Ohio Div. of Geol. Surv. Bull. 18. 160 p.

Bradley CP. 1906. Journal of Cyrus P. Bradley. Twiss GH, editor. Ohio Archaeol. and Hist. Quart. 15:207-70.

Briggs C Jr. 1938. Ohio geological survey first annual report: Geological report. Columbus, OH: Ohio Division of Geological Survey. p. 71-98.

Butts C. 1922. The Mississippian Series of eastern Kentucky. The Kentucky Geol. Surv. Series 6:7. 188 p.

Chaplin JR. 1980. Stratigraphy, trace fossil associations, and depositional environments in the Borden Formation (Mississippian), northeastern Kentucky: Annual field conference of the Geological Society of Kentucky. Lexington, KY: Geological Survey. 11:114 p.

Chaplin JR. 1982. Field guidbook to the paleoenvironments and biostratigraphy of the Borden and part of the Newman and Breathitt Formations (Mississippian-Pennsylvanian) in northeastern Kentucky. Oxford, OH: 12th Annual Field Conference of the Great Lakes Section SEPM. 190 p.

Churcher PL, French PR, Shaw JC, Schramm LL. 1991. Rock properties of Berea sandstone, Baker dolomite, and Indiana limestone. In: Proceedings of the 1991 SPE International Symposium on Oilfield Chemistry. Anaheim, CA: Society of Petroleum Engineers. p. 20-22. https://doi. org/10.2118/21044-MS

Commission on Chicago Landmarks. 2011. Landmark designation report: Holden block 1027 West Madison Street. 26 p.

Conca JL, Rossman GR. 1982. Case hardening of sandstone. Geology. 10(10):520-523. https://doi.org/10.1130/00917613(1982) $10<520: \mathrm{CHOS}>2.0 . \mathrm{CO} ; 2$

Demases TJ, McPherson JG. 1984. Delta-toe turbidite sedimentation in the Borden Formation (Mississippian) of northeastern Kentucky. Geol. Soc. Am. Abs. 16(3):132-133.

Destruction and Restoration. 1891. In: Industrial Chicago: the building interests. Chicago: The Good Publishing Co. p. $108-148$.

Duzan JB. 1880. Special Schedule of Manufactures Nos. $11 \&$ 12, Washington Township, Scioto County, Ohio, June 1, 1879-May 311880.

Ettensohn FR, Barnet SF, Chestnut DR, Eble CF, Goodmann PT, Greb SF, Lierman RT, Mason CE, Pashin JC, Schumacher GA. 1992. Changing interpretations of Kentucky geology: layer-cake, facies, flexure, and eustasy. Columbus, OH: Ohio Division of Geological Survey. 184 p. Ohio Miscellaneous Report 5.

Evans NW, Stivers EB. 1900. A history of Adams County Ohio from earliest settlement to present time. West Union, $\mathrm{OH}$ : Stives EB. 946 p.

Foreman F, Thomsen HL. 1940. Textural and shape variation in the Berea sandstone of Ohio. J Sediment Res. 10(2):4757. https://doi.org/10.1306/D4269080-2B26-11D7$8648000102 \mathrm{C} 1865 \mathrm{D}$

Freestone. 1892. Stone. 5:xvii.

Glastetter MJ, Switanowski RJ, editors. 2002. The Basilica of Saint Josaphat Milwaukee. Milwaukee, WI: Basilica of Saint Josaphat. 72 p.

Hannibal JT. 1995. Use of trace fossils in determining provenance of dimension stone: an example from Ohio. In: Maniatis Y, Herz N, Basiakos Y, editors. The study of marble and other stones used in antiquity: ASMOSIA III Athens. Transactions of the 3rd International Symposium of the Association for the Study of Marble and Other Stones Used in Antiquity. London: Archetype. 253-258.

Hannibal JT, Davis RA. 1992. Guide to the building stones of downtown Cincinnati: A walking tour. Ohio Division of Geological Survey Guidebook 7. 44 p.

Hannibal JT, Saja DB, Thomas SF, Hubbard DK. 2006. Quarrying history and use of Berea Sandstone in northeastern Ohio. In: Reid JC, editor. Proceedings of the 42nd Forum on the Geology of Industrial Minerals; 2006 May 7-13; Asheville, North Carolina. North Carolina Geological Survey Information Circular 34. Raleigh, NC: NC Division of Land Resources. 195-214.

Hannibal JT, Thomas SF, Noll MG. 2009. Maximilian, Prince of Wied's trip along the Ohio \& Erie Canal in 1834: An annotated new translation. Ohio History. 116:5-25. https:// doi.org/10.1353/ohh.0.0053

Hawes GW, Merrill GP, et al. 1884. Report on the building stones of the United States and statistics of the quarry industry. Census of mineral industries for 1880. 10(3) 10th Census (MI 1880.3), Bureau of the Census. Washington, D.C.: Gov't Print. Off. 410 p.

Herrick CL. 1891. The Cuyahoga Shale and the problem of the Ohio Waverly. Geol Soc Am Bull. 2(1):31-48. https://doi. org/10.1130/GSAB-2-31

Howe H. 1908. Scioto County: Historical collections of Ohio. Vol. 2 of 2. Cincinnati, OH: CJ Krehbiel \& Co. p. 557-571.

Hull DH, Larsen GE, Slucher ER. 2004. Generalized columns of bedrock units in Ohio. Columbus, OH: Ohio Division of Geological Survey. 1 p.

Hyde JE. 1915. Stratigraphy of the Waverly formations of central and southern Ohio: part II Cuyahoga Formation. J Geol. 23(8):757-779. https://doi.org/10.1086/622291

Hyde JE 1953. The Mississippian formations of central and southern Ohio. Marple MF, editor. Ohio Div. of the Geol. Surv. Bull. 51.

Julien, A. A., 1884, New York City and environs. In: Hawes GW, Compiler. Report on the Building Stones of the United States and Statistics of the Quarry Industry for 1880: U. S. Census, p. 313-335.

Kentucky Geological Survey. 1876. A general accounting of the commonwealth of Kentucky. Cambridge, MA: John Wilson and Son. 99 p.

Koch AC. 1972. Journey through a part of the United States of North America in the years 1844 to 1846 . Stadler EA, translator and editor. Carbondale, IL: Southern Illinois University Press, 177 p.

Lierman RT, Mason CE, Pashin JC, Ettensohn FR. 1992. Cowbell Member, Nancy Member, Farmers Member and Henley Bed of the Borden Formation, Sunbury Shale, and the Bedford-Berea sequence along State Route 546 in northeastern Kentucky. In: Ettensohn FR, editor. Changing interpretations of Kentucky geology: Layer-cake, facies, flexure, and eustacy. Field Trip 15 
for the Annual Meeting of the Geological Society of America, Cincinnati, Ohio. Miscellaneous Report 5. Columbus, $\mathrm{OH}$ : Ohio Division of Geological Survey. p. 142-145.

Livingston RA, Grissom CA, Aloiz EM. 2015. The Building Stones of the National Mall. In Brezinski DK, Halka JP, Ortt RA Jr., editors. Tripping from the Fall Line: Field excursions for the GSA Annual Meeting; 2015; Baltimore, Maryland. Geol. Soc. Am. Field Guide 40. p. 543-571.

Locke J. 1838. Ohio Geological Survey: Dr. Locke's report. Columbus, OH: Ohio Division of Geological Survey. p. 201-274. 2nd Annual Report.

Locke J. 1900. Part II: Geology and mineralogy. In: Evans NW, Stivers EB, editors. A history of Adams County, Ohio. West Union, OH: Stivers EB. p. 9-19.

M. Coe \& Sons. 1898. The Portsmouth Blade. 22(53): 50.

Merrill GP. 1886. The collection of building and ornamental stone in the U. S. National Museum: a hand-book and catalogue. In: Report of the United States National Museum, Part 2. Washington, D.C. p. 277-648.

Orton E. 1874. Report on the geology of Pike County: Report on the Geological Survey of Ohio. Geology and Palaeontology. 2(1):611-641.

Orton E. 1884. Report of the geological survey of Ohio vol. 5: Economic geology. Columbus, $\mathrm{OH}$ : Ohio Division of Geological Survey. 1124 p.

Orton E. 1891. The geography and geology of Ohio. In: Howe H. Historical collections of Ohio. Vol. 1 of 3. Columbus, $\mathrm{OH}$ : Henry Howe and Son. p. 59-89.

Otway. 1893. Stone. 8: xviii.

Portsmouth Blue and Buff Stone. 1893. Stone. 8: xxix.

Prosser CS. 1902. The Sunbury Shale of Ohio. J. Geol. 10(3):262_312. https://doi.org/10.1086/621003

Prosser CS, Cumings ER. 1904. The Waverly formations of central Ohio. Am. Geol. 34(6):335-361.

Roebling JA. 1867. Report of John Roebling, civil engineer to the president and board of directors of the Covington and Cincinnati Bridge Company. In: Covington and Cincinnati Bridge Company. Annual report of the president and directors to the stockholders of the Covington and Cincinnati Bridge Company. For the year ending Feb. 28th, 1867. Trenton, [state not given]: Murphy \& Bechtel. p. 11-92.

Sandy MR. 1992. Geologic Glimpses from Around the World - The Geology of Monuments in Woodland Cemetery and Arboretum, Dayton, Ohio: A Self-guided Tour. Guidebook No. 18. Columbus, OH: Ohio Division of Geological Survey. 29 p.

Schumacher GA, Mott BE, Angle MP. 2013. Ohio's geology in core and outcrop: A field guide for citizens and environmental and geotechnical investigators. Information Circular 63. Columbus, OH: Ohio Division of Geological Survey. 191 p.

Stivers EB. 1900. Part II: Township histories. In: Evans NW, and Stivers EB, editors. A history of Adams County, Ohio: West Union, OH: Stivers EB. p. 411-946.

Stout W. 1944. Sandstones and conglomerates in Ohio. Ohio J. Sci. 44(2):75-88. http://hdl.handle.net/1811/3395

Stockdale PB. 1939. Lower Mississippian rocks of the east-central interior. Geol. S. Am. S. 22. 248 p.

The Ohio Freestone District. 1892. Stone. 5: 191-196.

The Wardwell stone quarrying and channeling machine. 1888. Stone. 1(3): 74-78.

United States Geological Survey (USGS). US Geologic Name Lexicon ("Geolex"). [accessed 2016 Nov 4] https://ngmdb. usgs.gov/Geolex/search.
Walker JD, Cohen HA. 2006. The Geoscience handbook: AGI data sheets. 4th edition. Alexandria, VA: American Geological Institute. 302 p.

Waverly Blue Buff and Brown Sand and Free Stone. 1892. Stone. 5: xv.

Wentworth CK. 1922. A scale of grade and class terms for clastic sediments. J. Geol. 30(5):377-392. https://doi. org/10.1086/622910

Wied M. 1841. Reise in das Innere Nord-America in den Jahren 1832 bis 1834 v2. Coblenz: Hölscher.

Willis AO. 1996. Trace and Body Fossils from the Cuyahoga Formation (Mississippian), Reynoldsburg, Ohio [thesis]. [Columbus, $(\mathrm{OH})$ ]: Ohio State University.

Wilmarth MG. 1925. The geologic time classification of the United States Geological Survey compared with other classifications (accompanied by the original definitions of era, period, and epoch terms). US Geol. Surv. Bull. 769. 138 p.

Wolfe GR. 1996. Chicago: In and around the Loop - Walking tours of architecture and history. New York: McGraw-Hill. 465 p.

Wolfe ME. 2003. Hunting an Elusive Quarry: Geology and Early Stone Architecture in Ohio. In: Castor SB, Papke KG, and Meeuwig RO, editors. Betting on Industrial Minerals-Proceedings of the 39th Forum on the Geology of Industrial Minerals: Nevada Bureau of Mines and Geology Special Publication 33, pp. 263-270.

Wolfe ME, Stucker JD, compilers. 2014. 2013 Report on Ohio mineral industries: An annual summary of the state's economic geology. Columbus, $\mathrm{OH}$ : Ohio Division of Geological Survey. 38 p. 